\title{
Physicochemical characteristics of port dredging sediments and of the brick slip used in the manufacture of bricks: a comparative study
}

\author{
D. Benyerou, N. Boudjenane \& M. Belhadri \\ Rheology Laboratory, Transportation and Handling of \\ Complex Fluids (LRTTFC), Department of Hydraulics, \\ Faculty of Architecture and Civil Engineering, \\ University of Science and Technology of Oran (USTO-MB), Algeria
}

\begin{abstract}
The dredging practices are a major challenge for the development and maintenance of port activities. Millions of cubic meters are extracted regularly from Algerian ports, it is necessary to value them. This study focuses on the development of marine sediments from the port of Bethioua for making bricks. A physicochemical, mineralogical and fine microscopic characterization was done with great care for these marine sediments and for the slip brick at several laboratories in our university (USTO-MB). The physicochemical, mineralogical and microscopic characterization of materials shows a similarity between these sediments. They can be a very useful source of local raw materials, particularly for the building sector such as bricks.

Keywords: marine sediments, dredging, recycling, brick slip, characterization, port.
\end{abstract}

\section{Introduction}

In recent decades, the manufacture of bricks was assessed using the marine and river sediments worldwide [1-10]. The objective of this work is to characterize the physicochemical properties of marine sediments in the port of Bethioua and to examine two research issues applied to reduce the tonnage of dredged materials and to promote them in the brick manufacturing research. 
Most building materials are heterogeneous. These materials can therefore accommodate different types of inorganic waste whether they are treated or untreated. Several studies have been conducted in recent years in this area, adding sludge from sewage treatment plants and their ashes, waste of natural stone, slag, waste metal, sandy cuttings, etc. $[11,12]$.

\section{Materials and method used}

The studied sediments were collected in the harbor of what is now known as the town of Bathioua dedicated exclusively to oil activities (see Figure 1). The raw materials used for the manufacture of bricks are of two basic types: the clay and sand.

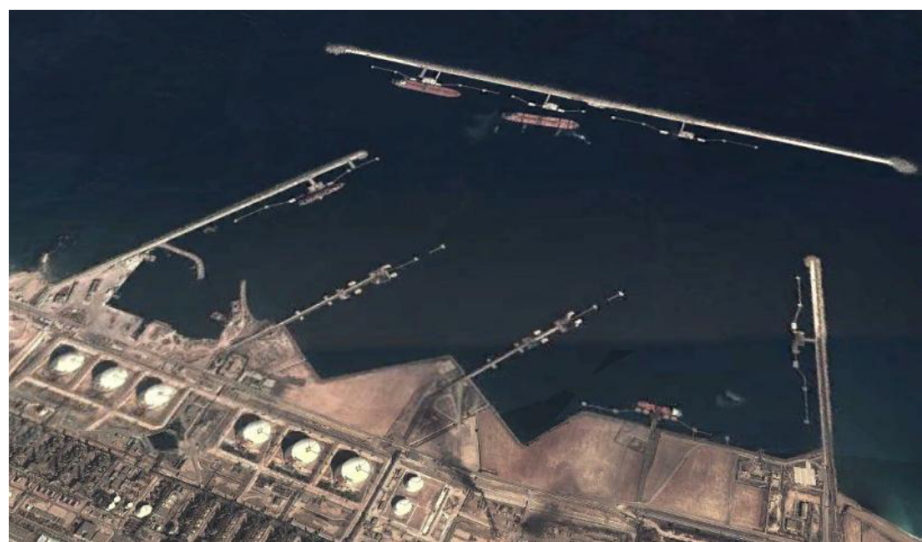

Figure 1: Sediment sampling site (Port of Bathioua).

The studied sediments were collected using a mechanical dredge which is basically an excavator mounted on a pontoon. Samples were collected from the Bathioua locality. This area is classified as oil zone, which explains the high levels of hydrocarbons in these sediments. The dredged material was homogenized and stored in clean waterproof bags and transferred the same day to different laboratories. The study includes a set of physical properties determination such as state parameters, nature, water content and grain distribution, the study includes also chemical properties determination like $\mathrm{pH}$, conductivity, organic matter and hydrocarbons, it determining mineralogical and microscopic properties is also part of the study.

\subsection{Physical properties}

The water content was determined according to NF P94-050 standard and the true density was determined according to NF P94-054 standard. The results are shown in Table 1. The particle size analysis was carried out by wet process on a series of sieves of the XP P94-041 standard (see Figure 2). The granulometric curve shows 
the presence of a clay fraction of the order of $2 \%$, siliceous fraction of the order of $20 \%$ and a sand fraction in the order of $78 \%$, particle diameters of $\mathrm{d} 10=3$ microns and $\mathrm{d} 90=270$ microns.

Table 1: Physical and chemical parameters of the materials studied.

\begin{tabular}{|ccc|}
\hline Settings & $\begin{array}{c}\text { Marine } \\
\text { sediment }\end{array}$ & $\begin{array}{c}\text { Clay } \\
\text { brick }\end{array}$ \\
\hline Density (g/cms $)$ & 2.2 & 2.6 \\
Fraction $<63 \mu \mathrm{mm}(\%)$ & 58 & $s 8$ \\
Fractions $>63 \mu \mathrm{m}(\%)$ & 42 & 12 \\
Wp (\%) & 30.0 & 49.8 \\
WL (\%) & 18.9 & 25.7 \\
IBS (\%) & 1.56 & 5.3 \\
O.M (\%) & 1.88 & 3.66 \\
pH & 8.7 & 8.1 \\
Conductivity & $361 \mathrm{~ms}$ & $169 \mu \mathrm{s}$ \\
\hline
\end{tabular}

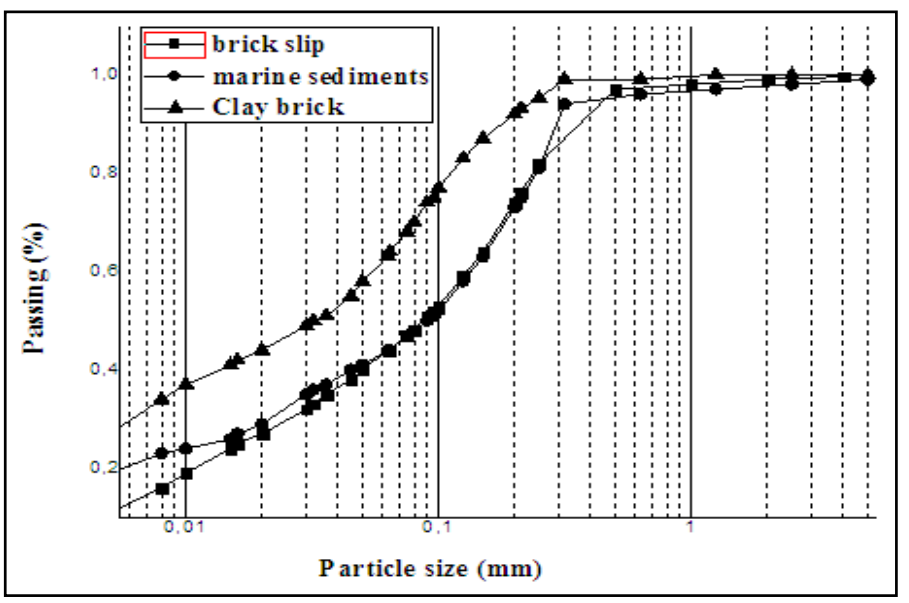

Figure 2: Curves of marine sediment grain size, clay brick and brick slip.

The Atterberg limits were carried out according to the NF P94-051 standard with liquid limit $\mathrm{WL}=30.2 \%$ and a plastic limit $\mathrm{Wp}=19.6 \%$ for marine sediments. However, for the clay used in the manufacture of bricks, these values are respectively in the range of $50.1 \%$ and $25.2 \%$. 


\subsection{Chemical properties}

Table 1 shows the chemical properties such as $\mathrm{pH}$, conductivity, organic matter and hydrocarbon. The $\mathrm{pH}$ was determined according to the NF X31-103 standards, electrical conductivity was measured with a conductivity cell calibrated according to the DIN ISO 11265 standard, the measurement of the organic material was carried out using the XP P94-047 standard and finally the elements traces were determined by atomic absorption spectrometry. The results are summarized in Table 2 and show that there's a presence of hydrocarbons in marine sediments. Between N1 and N2 levels, further investigation may be necessary depending on the specific project and the degree of exceeding the level N1. Tests are then performed to assess the overall toxicity of sediments.

Table 2: Relative levels to trace elements (in $\mathrm{mg} / \mathrm{kg}$ dry sediment analyzed on the fraction smaller than $2 \mathrm{~mm}$ ), GEODE (2000).

\begin{tabular}{|c|c|c|c|c|c|}
\hline Metals & Units & $\begin{array}{l}\text { Marine } \\
\text { Sediment }\end{array}$ & Clay brick & $\begin{array}{c}\text { Level } \\
1\end{array}$ & $\begin{array}{c}\text { Level } \\
2\end{array}$ \\
\hline Lead $(\mathrm{Pb})$ & $\mathrm{mg} / \mathrm{kg}$ & $<0.01$ & $<0.01$ & 100 & 200 \\
\hline Mercury (Hg) & $\mathrm{mg} / \mathrm{kg}$ & $<0.01$ & $<0.01$ & 0.4 & 0.8 \\
\hline Chromium (Cr) & $\mathrm{mg} / \mathrm{kg}$ & $<0.005$ & $<0.005$ & 90 & 180 \\
\hline Cadmium (Cd) & $\mathrm{mg} / \mathrm{kg}$ & $<0.01$ & $<0.01$ & 1.2 & 2.4 \\
\hline Arsenic (As) & $\mathrm{mg} / \mathrm{kg}$ & $<0.05$ & $<0.05$ & 25 & 50 \\
\hline $\operatorname{Tin}$ & $\mathrm{mg} / \mathrm{kg}$ & $<0.01$ & $<0.01$ & / & / \\
\hline nitrite & $\mathrm{mg} / \mathrm{kg}$ & 0.00 & 0.00 & 37 & 74 \\
\hline phenol & $\mathrm{mg} / \mathrm{kg}$ & 0.017 & 0.017 & / & / \\
\hline total hydrocarbon & $\mathrm{mg} / \mathrm{kg}$ & 1.010 & 0.441 & 1 & l \\
\hline
\end{tabular}

To get a better idea about the chemical composition of the materials studied, we conducted an X-ray fluorescence test. The results are summarized in Table 3 and expressed in weight percentage. This detailed analysis of the results is based on the comparison of the various oxides levels, which show that alumina $\left(\mathrm{Al}_{2} \mathrm{O}_{3}\right)$ is related to the plasticity and the contents of this oxide reported in our clay used for the manufacture of brick is greater than the content of marine sediments. To increase the plasticity it is necessary to mix up these marine sediments with bricks clay.

Table 3: Chemical composition of major elements in materials.

\begin{tabular}{|ccccccccccccc|}
\hline $\begin{array}{c}\text { Oxide content } \\
\text { (mass\%) }\end{array}$ & $\mathrm{S}_{\mathbf{i}} \mathbf{O}_{2}$ & $\mathrm{Al}_{2} \mathbf{O}_{3}$ & $\mathrm{Fe}_{2} \mathbf{O}_{3}$ & $\mathbf{C a O}$ & $\mathbf{M g O}$ & $\mathbf{S O}_{3}$ & $\mathbf{K}_{2} \mathbf{O}$ & $\mathbf{N a}_{2} \mathbf{O}$ & $\mathbf{C l}$ & $\mathrm{P}_{2} \mathbf{O}_{5}$ & $\mathbf{T}_{i} \mathbf{O}_{2}$ & $\mathbf{L O I}$ \\
\hline $\begin{array}{c}\text { Marine } \\
\text { sediments }\end{array}$ & 27.9 & 6.1 & 4.01 & 29.4 & 2.71 & 0.85 & 0.70 & 0.34 & 0.02 & 0.11 & 0.18 & 28.9 \\
Clay brick & 48.4 & 12.2 & 7.72 & 10.7 & 2.50 & 0.70 & 2.03 & 0.55 & 0.05 & 0.21 & 0.56 & 16.1 \\
Brick slip & 61.0 & 12.1 & 5.48 & 9.05 & 1.76 & 0.04 & 1.13 & 0.46 & 0.13 & 0.11 & 0.72 & 7.80 \\
\hline
\end{tabular}

The levels of silica $\left(\mathrm{SiO}_{2}\right)$ in marine sediments are roughly classified within standards. This oxide $\left(\mathrm{SiO}_{2}\right)$ is due to the presence of quartz which shows a sufficient amount to act as a degreasing agent without addition of an inert element such as sand. 
The iron oxide $\left(\mathrm{Fe}_{2} \mathrm{O}_{3}\right)$ is the main colorant in clays and is responsible for the red color after cooking. Lime $(\mathrm{CaO})$ content is high for marine sediments.

\subsection{Mineralogical properties}

Figures 3, 4 and 5 show mineralogical identification made from qualitative XRD analysis performed on a crushed fraction of about $80 \mu \mathrm{m}$ of marine sediments, for slip bricks a Bruker D8 diffractometer was used. The results show the presence of quartz, calcite and dolomite as major minerals.

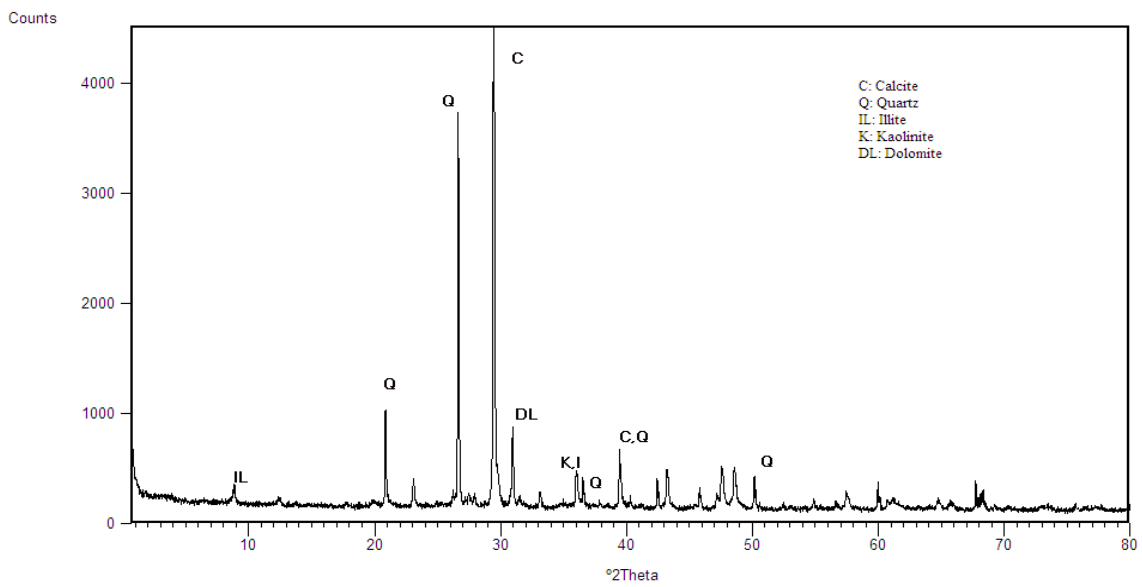

Figure 3: XRD diffractogram of marine sediments.

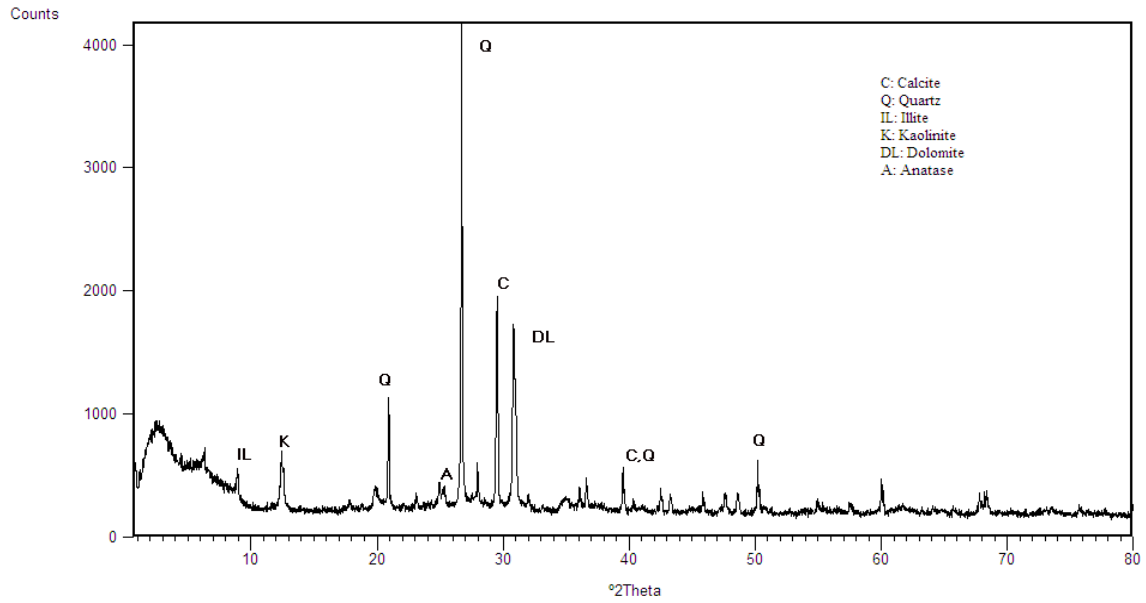

Figure 4: XRD diffractogram of clay brick. 


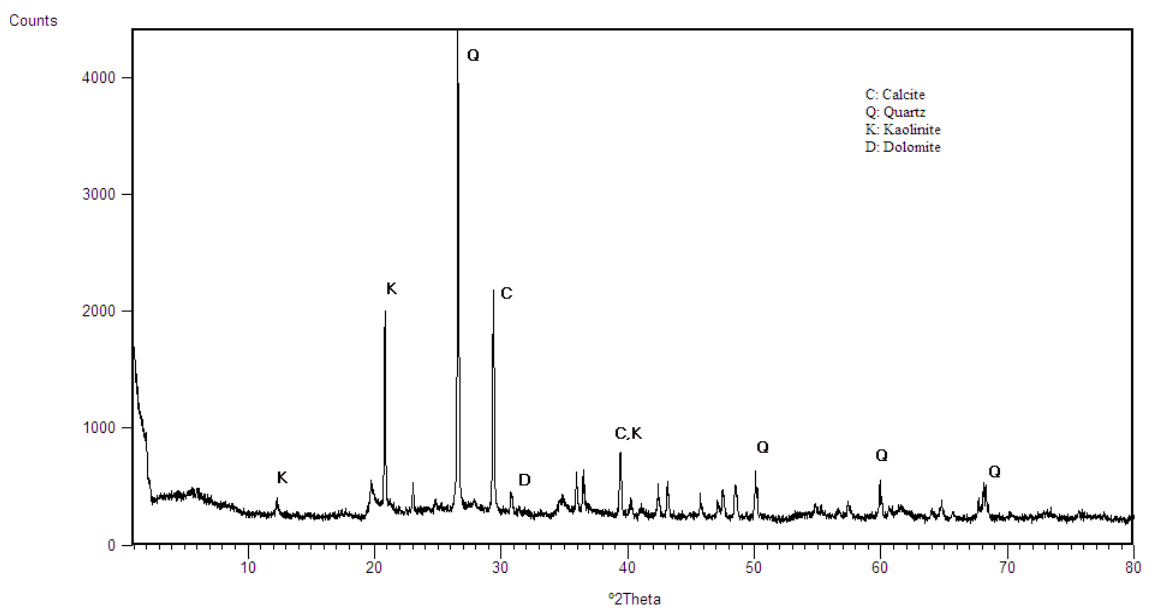

Figure 5: $\quad$ XRD diffractogram of the brick.

\subsection{Properties microscopic}

Microscopic study revealed the presence of a white product in marine sediments. This product may be due to the high salinity which was detected by the high value of the conductivity which is relatively higher than that of the slurry brick. It is also noted from Figures 6, 7 and 8 that the grains are highly variable in shape and size, they are formed by the agglomeration of grains of smaller sizes ( $\approx 1$ micron).

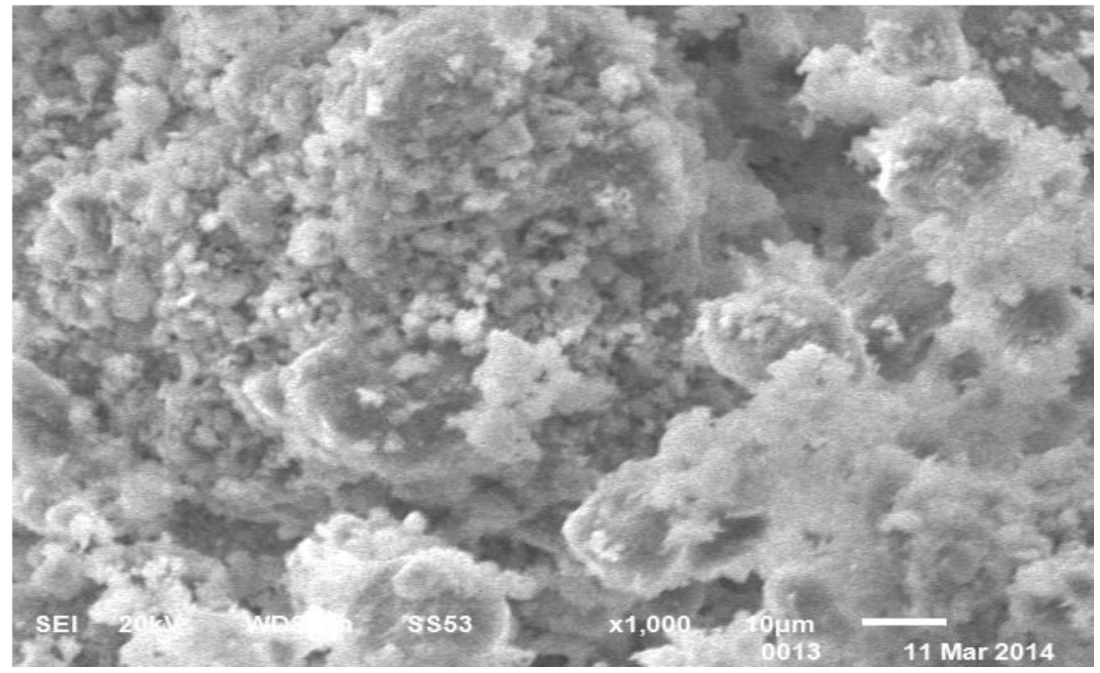

Figure 6: Microscopic analysis of the clay brick. 


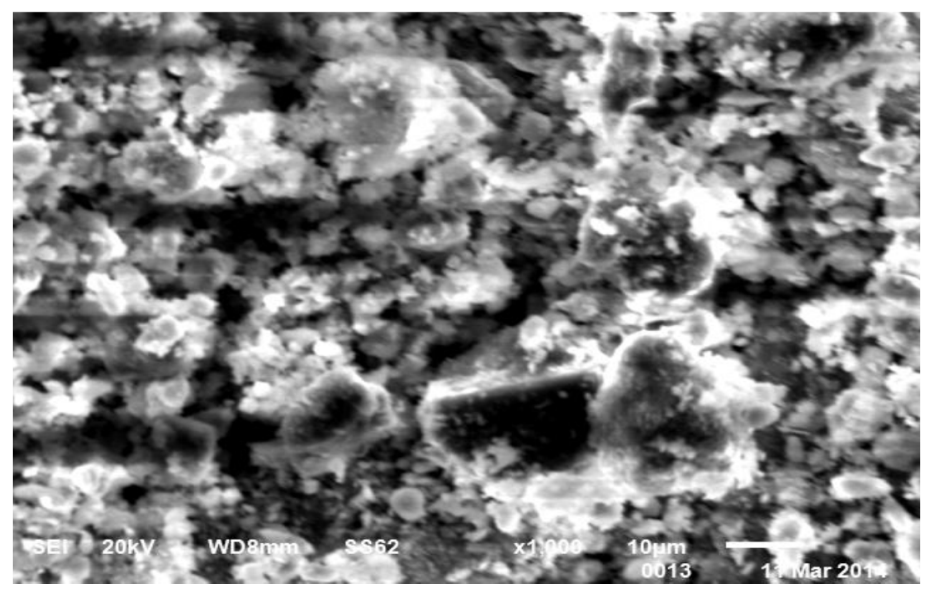

Figure 7: Microscopic analysis of marine sediment.

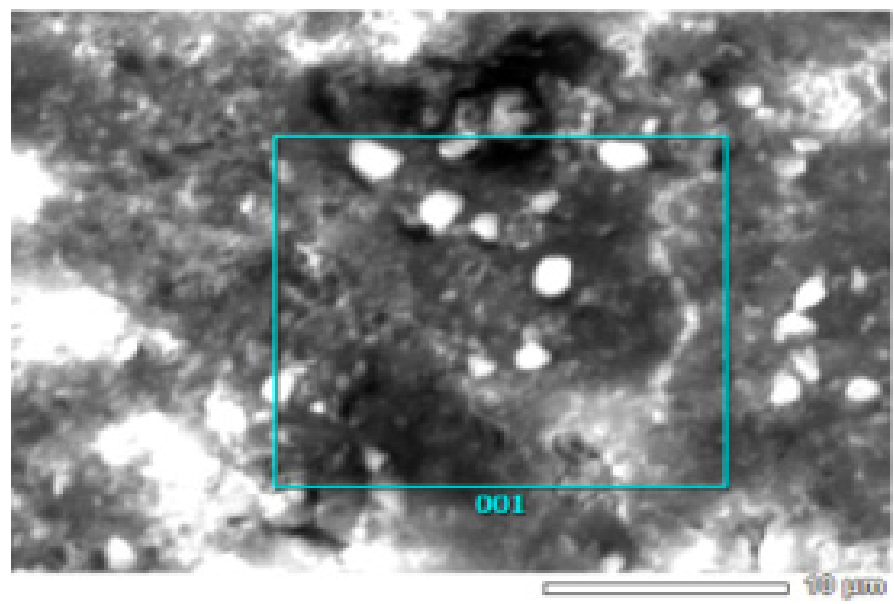

Figure 8: Microscopic analysis of the brick slip.

\section{Conclusion}

The physical characterization of port dredging sediment from the locality of Bathioua shows that these sediments are valuable materials and may constitute a source of the production of bricks. Chemical characterization of the sediments was used to evaluate their potential for use with the necessary need to mix these marine sediments with clay bricks to increase their plasticity. Bathioua port dredging sediment, however, has a high rate of hydrocarbons due to the nature of the port activity. We particularly noticed the absence of metal pollution.

It appears that these sediments with grain size comparable to that of the brick slip can be attractive economic raw materials for local construction companies, 
especially brick factories. The mineralogical characterization of marine sediments appears similar to that of the clay used to make bricks. This shows that the recovery of sediment in the brick production industry is a very promising step to be taken to promote local economy.

\section{References}

[1] Hamer et Karius, 2002.Brick production with dredged harbour sediment an industrial-scale experiment. Waste Management. 22, 2002, pp. 521-530.

[2] Lafhaj et al., Polluted river sediment from the north region of France: Treatment with NOVOSOL process and valorization in clay bricks. Construction and building materials. 22, 2008, pp. 755-762.

[3] Samara et al., Valorization of stabilized river sediment in fired clay bricks: Factory Scale experiment. Journal of Hazardous Materials. 163, 2009, pp. 701-710.

[4] Yang xu et al., The use of urban river sediments as a primary raw material in the production of highly insulating brick. Ceramic International. 40, 2014, pp. 8833-8840.

[5] Andrea et al., Utilization of savannah harbor river sediment as the primary raw material in production of fired brick. 113, 2012, pp. 128-136.

[6] M. Romero et al., Sintering behavior of ceramic bodies from contaminated marine sediment. Ceramic International. 34, 2008, pp. 1917-1924.

[7] Keang sépouv et al., Rheometric characterization of solid transition conditions/liquid cohesive sediments.

[8] Benamar et al., Caractérisation rheological and dredged sediment. Paralia journal. DOI: 10.5150/jngcgc.2012.108-B.

[9] Levachie et al., 2011. Valuation pilot unit in Mediterranean sediments Study of the geotechnical characteristics and permeability, vol.4, pp. 1-4.20. doi; 10.5150, review paralia, 2011, 004.

[10] L. Ben Allal, Ammari M., Frari., Azmani A., Belmoukhtar E., (2011). Characterization and optimization of dredged sediment from the ports of Tangier and Larache (Morocco) .Revue Paralia, vol 4, pp. 5.1-5.13.

[11] Marie Loustau cazalet. Physico-chemical characterization of a marine sediment treated with hydraulic binders-evaluation of the potential mobility of pollutants National inorganiques thèse l'institut of Applied Sciences Lyon. 2012.

[12] Thamh Binh NGYYEN, dredged sediment Valuation treated with NOVOSOL ${ }^{\circledR}$ process from materials to the foundations of mechanical and environmental-floor behavior. Thesis at the University of TOULOUSE. 2008 . 